\title{
Urban Regreeneration: Green Urban Infrastructure as a Response to Climate Change Mitigation and Adaptation
}

\author{
Jon Laurenz Senosiain
}

Architecture \# 137, School of Architecture, the University of the Basque Country, Barrio Sarriena, Leioa 48940, Bizkaia, Spain

Corresponding Author Email: jlaurenz001@ikasle.ehu.eus

https://doi.org/10.18280/ijdne.150105

Received: 22 July 2019

Accepted: 5 August 2019

\section{Keywords:}

climate change adaptation urban solutions, green urban infrastructure, green streets, low impact development, nature based urban solutions, stormwater management, sustainable urban drainage system, urban regreeneration

\begin{abstract}
This research focuses on how green urban infrastructure contributes to adapt and mitigate climate change consequences. It analyses the benefits derived from an overall green urban regeneration, including green roofs, green façades and sustainable urban drainage. This would contribute to both climate change adaptation and mitigation solutions, including the following: reduction in cooling and heating demand; bio-retention of stormwater and consequently ameliorating risks of floods; reducing hot spots which create urban heat island and improving urban health. This paper first categorizes green urban infrastructure solutions. It analyses a series of case studies conducted in Germany, Spain, Canada and the USA; in order to identify the contribution to mitigate and adapt to climate change. It develops a set of measurable figures which define the contribution of an overall green urban solution intervention. It applies this assessment specifically to an urban space of Amurrio (Araba, Spain) and to an existing building of Balmaseda (Bizkaia, Spain). It finally analyses evaluation tools for governments and planning institutions to improve planning strategies and policy developments. The paper presents the results, concluding that climate change mitigation and adaptation green urban solutions are mainly achieved when applied in the larger scale of a whole city.
\end{abstract}

\section{INTRODUCTION}

This paper argues the need of overall green urban interventions in order to respond to climate change consequences. After the International Paris Agreement of December 2015 [1], which was a turning point on the international compromise of countries around the world to strengthen the global response to the threat of climate change; together with the more recent IPCC Climate Change Report of October 2018 [2], which calls for urgent actions in order to limit climate change impacts; this research proposes new urban regeneration designs based on deep green urban interventions: urban regreeneration

But do these green urban interventions make sense? Are they worth it? Under what terms are these environmental benefits achieved? This research attempts to bring clarity on the suitability of such green urban interventions. It analyses the degree to which these environmental goals are achieved by implementing these concepts into two real projects in small Basque municipalities: Balmaseda, and Amurrio. It proposes a combination of green roofs, green facades, and green urban design for these new urban regeneration projects. In doing so, overall and integrated green urban solutions would deeply ameliorate the impact of climate change, through mitigation solutions (green roofs and facades) and adaptation solutions (green streets, as well as green roofs and green facades). It finally provides urban planning tools for policy makers in order to implement these green urban interventions into urban regulations.

\section{METHODOLOGY}

This study begins with a preliminary analysis of the current practices of green urban infrastructure. It classifies them into two major categories: building scale - private - green urban infrastructure, and urban scale - public - green urban infrastructure. Within these two categories, distinct subcategories have been identified.

The research then identifies a broader set of opportunities for green urban infrastructures. It explores the expectations that such a green urban intervention would provide, which have been condensed into two main areas: First: adaptation solutions to climate change, in terms of ameliorating heat island effect, reducing the stormwater runoff and consequently the risk of floods, and contributing to water \& air quality (urban health); and second: mitigation solutions to climate change, in terms of energy efficiency and reduction in $\mathrm{CO}_{2}$ emissions.

The framework is tested in two case studies. The study applies the assessment specifically to an urban space of Amurrio (Araba, Spain) and to an existing building of Balmaseda and its garden (Bizkaia, Spain). In the case of the urban space in Amurrio, it is a car dominated urban space with a dramatic $95 \%$ of impervious dark pavement. The proposed regreeneration project urges to increase the greenery up to about $25 \%$ of the total urban surface, through green urban infrastructure solutions: such as, bioretention green areas, and bioretention pergolas, as climate change adaptation solutions. As for the case of the renovation of the existing building in Balmaseda and the garden next to it, climate change mitigation and adaptation solutions are implemented. Regarding the 
mitigation solutions those related to energy efficiency are designed, in terms of high insulation of building facades, roof and windows; reducing by more than $55 \%$ the building energy demand. Regarding the climate change adaptation solutions, the design includes a greenhouse integrated on the roof, combined with vegetated tiles and dry construction systems. In the garden similar green urban infrastructure solutions are implemented. The research provides comprehensive data on how these green urban solutions strategies contribute to mitigate and adapt to climate change.

This paper finally analyses evaluation tools for governments and planning institutions to improve planning strategies and policy developments. Through this exploration it initiates a methodology to create evaluation tools for policy makers to implement such a green urban intervention into urban regulations. It ends up with the conclusion and discussion of the paper. It reclaims further studies should be developed to enhance and broadly implement green urban regeneration projects; and it explores the expectations as well as the barriers that such a green urban intervention would provide.

\section{CATEGORIZATION OF GREEN URBAN INFRASTRUCTURE}

There are many terms around the globe referring to the concept of Green Urban Infrastructure: in Europe, for instance, it is quite common to use the concept of "Nature-Based Solutions" (NBS) and "Re-naturing cities" [3], when referring to climate change adaptation solutions. It is also frequent to find around the world the term of Sustainable Urban Drainage Infrastructure (SUD) [4] as well as "Urban re-vegetation" [5] when referring to this concept. More frequently in the US, and more specifically in the west coast of the US, it is common to refer to similar concepts under the term of Low Impact
Developments (LID) [6] or, in the case of Canada, it frequent to use the term of Green Streets [7]. This research proposes the term of Green Urban Infrastructure [8] as the most comprehensive one of all the different terminologies found during this analysis. It classifies them in two major categories: those related to a building component - Green Building Envelopes; and those associated to an urban public space: Green Urban Public Infrastructure.

\subsection{Green building envelopes: Green facades and green roofs}

Green Urban Infrastructure associated to Building Envelopes is split down into two main construction systems: Green Facades (or Green Walls) and Green roofs (or Living roofs); which are identified in the following distinct construction types:

\subsubsection{Green facades (also known as green walls)}

As described in previous research, green facades are classified in two major categories: those attached to an opaque wall - opaque green façades; and those associated to a transparent wall - transparent green façades (Figure 1). These, in turn, split into five subcategories: greenery climbing through an opaque wall, greenery attached to an opaque wall as a green tapestry, greenery composed of green vertical panels, greenery between two transparent layers and greenery in the external layer and a transparent wall as the internal layer [9].

\subsubsection{Green roofs (also known as living roofs)}

As for the case of green facades, green roofs are also classified into two major categories: extensive and intensive green roofs [10]. The thickness of the growing medium determines the type of roof: if it's moderate, $8-15 \mathrm{~cm}$ high, they are considered extensive green roofs; above that range they are intensive green roofs (Figure 2).

\begin{tabular}{lll|}
\hline & Types of Green Façade \\
\hline
\end{tabular}

Figure 1. Types of green facades

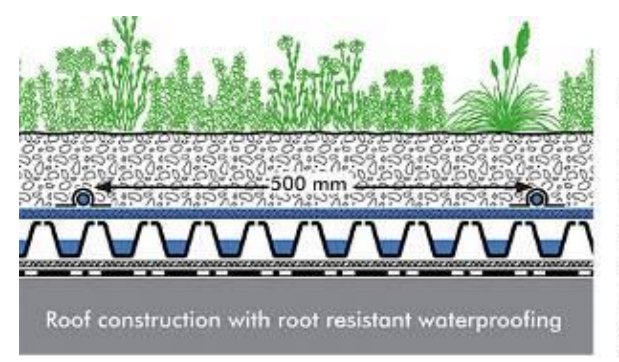

Plant Community "Rockery Type Plants" 


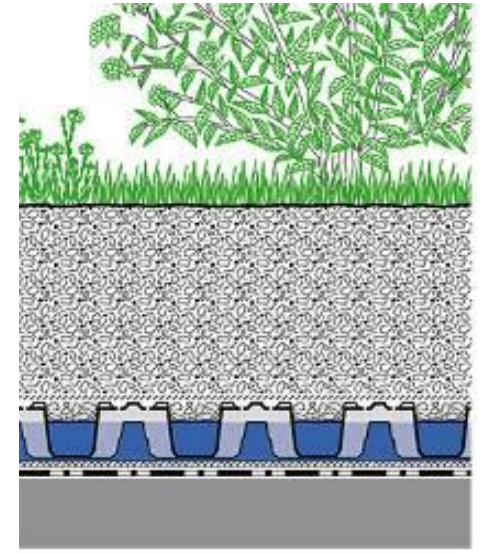

Lown and perennials; with a deeper

substrate level, bushes and small trees

System Substrate "Roof Garden"

$\geq 200 \mathrm{~mm}$

Filter Sheet SF

Floradrain FD 60 neo with

Zincolits Plus infill

Protection Mat ISM 50

Root Barrier WSB 100-PO,

if waterproofing is not root-resistant

Figure 2. Zinco green roof systems [11]

\subsection{Green urban public infrastructure}

Although urban parks are the classic green urban spaces of cities, in this Green Urban Public Infrastructure classification are not included since they are broad enough to be analyzed in another research specifically for them. Same has been considered for Green Corridors- Thus, in this classification four main groups have been categorized:

\subsubsection{Green canopies}

This paper distinguishes between two major green canopies: natural canopies like trees, or climbing plants; and artificial green canopies like pergolas, and trellis; usually associated with vegetation (Figure 3). Green Technology canopies, such as photovoltaic canopies, urban wind turbines, etc. although they certainly contribute to adapt to climate change by locally generating green energy; are not included in this classification. The following image shows some examples of these types of green canopies.
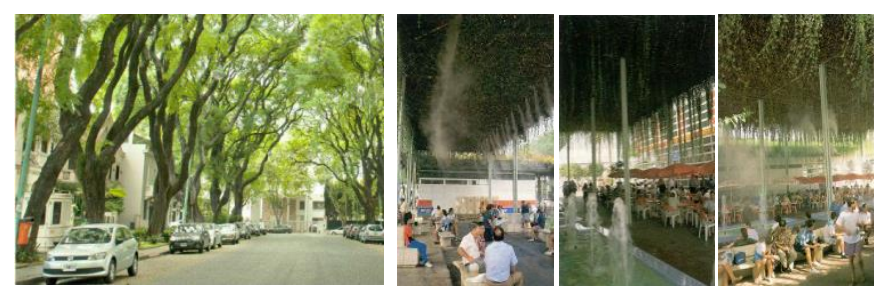

Figure 3. Natural green canopies (Research of the Entre Rios University, Argentina [12]) and artificial green canopies (Photos from the International Exposition in Seville 1992)

\subsubsection{Green infiltration systems}

Many different examples are within this type of green urban infrastructure, which are gathered in four major subcategories: Infiltration basins; Infiltration trenches; Filter drains; and swales (Figure 4).
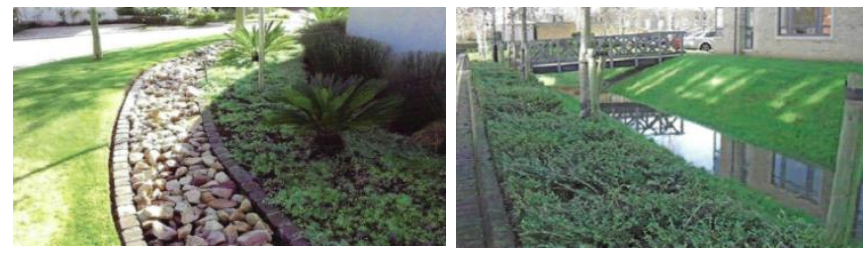

Figure 4. Images of different green infiltration systems: Trench drain and swales [13]

\subsubsection{Green pavements}

This paper considers as green pavements those that are permeable. There are two main types of green pavements: permeable pavements which can be either modular permeable pavements, or continuous permeable pavements; and pollutants trapping pavements (Figure 5). Those pavements that are impervious but let water pass through their joints are not included in this classification. The following image shows some examples of green pavements.
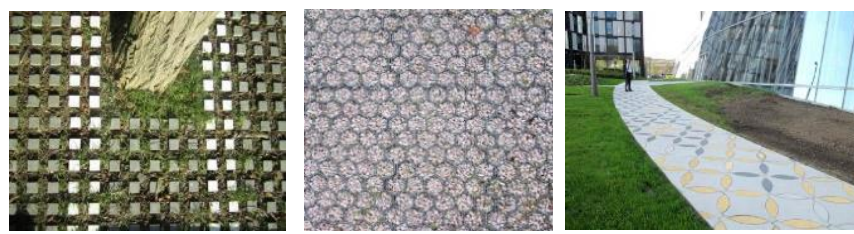

Figure 5. Images of different types of green pavements

\subsubsection{Bio-retention areas}

There are three subcategories of bio-retention areas: bioretention ponds; wetlands; and raingardens. As for previous categories some images show these different types of bioretention areas (Figure 6).
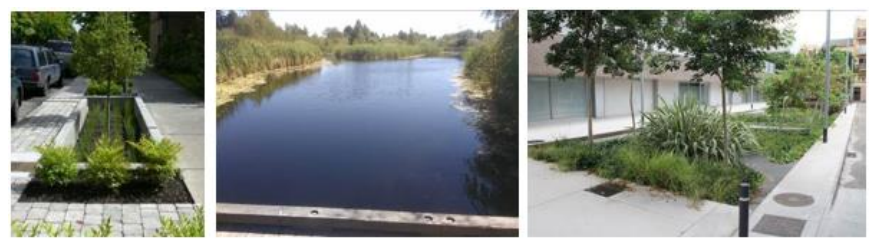

Figure 6. Images of different Bio-retention areas (by the author)

\section{CONTRIBUTION OF GREEN URBAN INTERVENTION TO MITIGATE AND ADAPT TO CLIMATE CHANGE: CASE STUDIES}

The research based on similar related research identifies a broader set of opportunities for green urban infrastructure. It explores the expectations that such a green urban intervention would provide, which have been condensed into two main areas: First: mitigation solutions to climate change, in terms of energy efficiency and reduction in $\mathrm{CO}_{2}$ emissions; and second: adaptation solutions to climate change, in terms of 
ameliorating heat island effect, reducing the stormwater runoff and consequently the risk of floods, contribution to water \& air quality (urban health). It applies this assessment specifically to an existing building of Balmaseda (Bizkaia, Spain); and to an urban space of Amurrio (Araba, Spain).

In the case of the renovation of the existing building in Balmaseda, six innovative solutions are proposed to mitigate and adapt to climate change: a greenhouse integrated under the roof associated to a sliding skylight; Vegetated Tiles; Dry Construction Systems (especially for floors); Green Urban Infrastructure based on water garden design; Water spray on the roof of the building; and the Treatment and reuse of rainwater and greywater. Following images (Figures 7 and 8) summarizes the proposed green intervention.
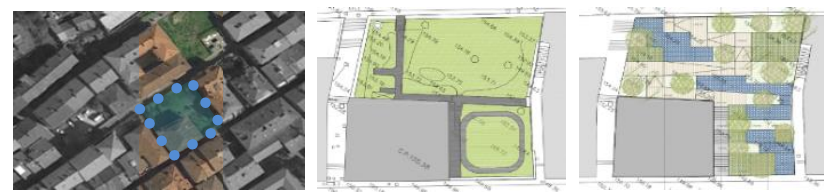

Figure 7. Water garden design solution for the lawn next to the building
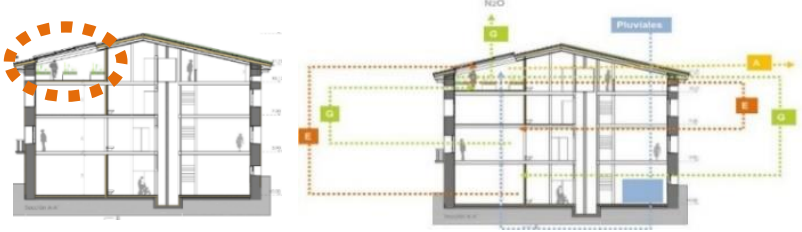

Figure 8. Greenhouse, vegetated tiles and special air conditioning system proposed for the renovation of the building

The research analyses the contribution of such renovation project, in terms of mitigation solutions, those related to green envelopes in buildings: green roofs and green walls. According to related research studies on green roofs, the energy required for space conditioning due to the heat flow through the green roof, would be reduced by more than $75 \%$ [14]. In addition, green walls contribute significantly to the reduction of indoor air temperature in the summer, by reducing the external air temperature of a west-facing orientation up to $4^{\circ} \mathrm{C}$ on a clear August day in Japan [15] and by $5^{\circ} \mathrm{C}$ in South Africa [16]. This cooling effect of plants could reduce the annual cooling energy use by $31 \%$, and windbreak plantings around unprotected homes would reduce annual heating energy use by $15 \%$ [17]. According to computer simulations, in a warm climate such as Madrid, cooling energy use reduction could reach up to $45 \%$ and heating reduction up to $23 \%$ [18]. This also means that $\mathrm{CO}_{2}$ emissions produced to generate this energy would be reduced by the same average. Thus, this paper estimates that around $10-15 \%$ of energy demand and consequently $\mathrm{CO}_{2}$ emissions would be reduced by this type of intervention.

For adaptation solutions to climate change, in terms of integrating bio-retention areas and sustainable urban drainage solutions in the design; related studies on urban parks suggest that for every $100 \mathrm{~m}^{2}$ of vegetation, air temperature is reduced by $1^{\circ} \mathrm{C}$, and that by increasing the ratio of green area to build area by $10 \%$ a $0.8^{\circ} \mathrm{C}$ reduction is achieved [19]. Similarly, Central Park in New York reduces its nearby temperature by $2-5^{\circ} \mathrm{C}$ [20], and Shinjuku Gyoen park in Tokyo reduces the urban heat island effect by $2^{\circ} \mathrm{C}$ and decreases the temperature in adjacent areas within the range of $80-90 \mathrm{~m}$ from the boundary [21]. Vegetated courtyards reduce air temperature approximately $4-5^{\circ} \mathrm{C}$ [22], and vegetated roofs reduce air temperature between $0.5-2^{\circ} \mathrm{C}$ [23].

Moreover, in terms of the capacity of plants to trap air pollutants such as $\mathrm{CO}_{2}$; grassy plants (on lawns) would trap $4.38 \mathrm{~kg} / \mathrm{m}^{2}$ per year; shrubby plants (on green roofs) would trap $8.76 \mathrm{~kg} / \mathrm{m}^{2}$; and climber plants (on green walls) would trap $6.57 \mathrm{~kg} / \mathrm{m}^{2}$ [24].

Therefore, in terms of the contribution of the proposed green renovation to climate change adaption, the research estimates that the $98.71 \mathrm{~m}^{2}$ of new vegetated tiles, which would behave like grass, would trap around $432,35 \mathrm{~kg}$ of $\mathrm{CO}_{2}$ per year. While the $38.36 \mathrm{~m}^{2}$ of plants of the community garden proposed under the roof, which would behave like shrubby plants; would trap $336.03 \mathrm{~kg}$ of $\mathrm{CO}_{2}$ per year.

In the case of the green regeneration project in Amurrio, four main green urban solutions are implemented: stormwater bioretention areas; green parking lot design, green shading devices (like pergolas); and new permeable pavements; as following images show (Figures 9 and 10).

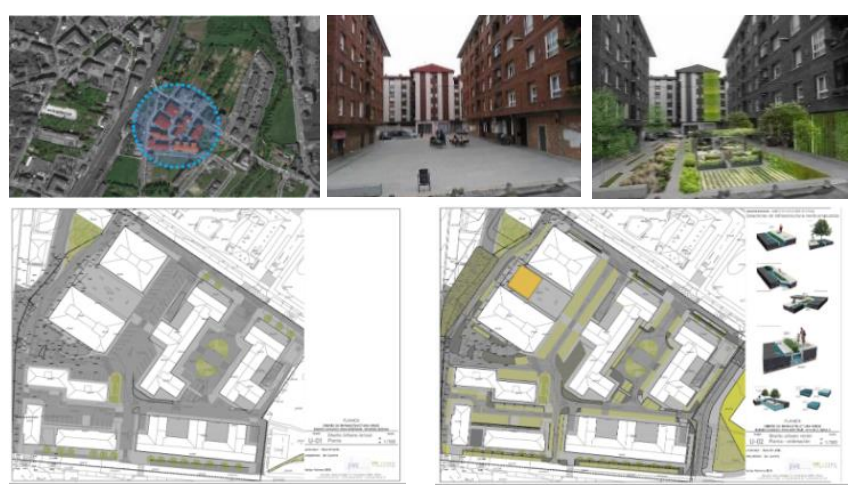

Figure 9. Images of the before and after the green urban design proposal

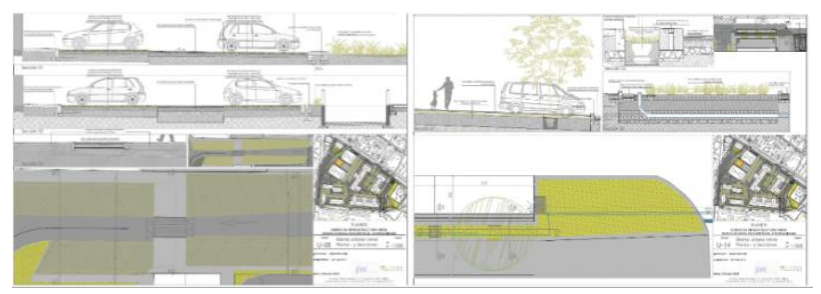

Figure 10. Technical drawings of the bio-retention areas proposed for the selected site

The total selected urban space area is a hectare $(10,987.10$ $\mathrm{m}^{2}$ ) which currently is divided in impervious pavements $\left(6,667.31 \mathrm{~m}^{2}\right.$ of asphalt: $60.7 \%$; and $3,822.48 \mathrm{~m}^{2}$ of stony pavement $34.8 \%$ ); and green space $\left(497.31 \mathrm{~m}^{2}\right.$ of grass, meaning the $4,5 \%$ ).

The new green urban design proposal increases by $2,305.89$ $\mathrm{m}^{2}$ new green areas (fundamentally in terms of bio-retention areas $689.61 \mathrm{~m}^{2}$ and green parking lots $1,616.28 \mathrm{~m}^{2}$ ). This means new green areas would reach the $21 \%$ of the total urban space. Besides, the design includes new green pergolas, as shading urban furniture, which area reaches $610.59 \mathrm{~m}^{2}(5.5 \%)$.

When analyzing the contribution of such new green urban intervention to the mitigation of climate change, the research focuses mainly on the $\mathrm{CO}_{2}$ trapped by the new greenery. It estimates that the new green parking lot area $\left(1,616.28 \mathrm{~m}^{2}\right)$ behaves as grassy plants when trapping and cleaning air 
pollutants. This means that this new green area would trap $7,079.31 \mathrm{~kg}$ of $\mathrm{CO}_{2}$ (according to the mentioned Schaefer research [24]. While the bio-retention areas $\left(689.61 \mathrm{~m}^{2}\right)$ are estimated to behave as shrubby plants. This means, according to the mentioned research [24] these areas would trap 6,040.98 $\mathrm{CO}_{2}$. Finally, the green pergolas area $\left(610.59 \mathrm{~m}^{2}\right)$, which are assumed to work as climbing plants; according to the same research [24], they would trap 4,011.58 $\mathrm{CO}_{2}$. In total, the proposed green intervention would contribute to Climate Change Mitigation by trapping $\mathrm{CO}_{2}$, and cleaning pollutants, by $17,131.87 \mathrm{~kg}$ of $\mathrm{CO}_{2}$.

Moreover, the contribution of the new green urban design proposal to climate change adaptation would be reached in terms of; reducing Urban Heat Island effect, cooling the temperature of the surroundings by $1-3^{\circ} \mathrm{C}[19,20]$; and consequently, reducing heat strokes events (and even deaths related to heat waves). It would also contribute to ameliorate the risk of floods by the proposed bio-retention areas and green pergolas, which would retain stormwater and delay the river level rise.

\section{URBAN TOOLS FOR PLANNING STRATEGIES REGULATION TOOLS FOR GOVERNMENTS AND POLICY MAKERS}

This section pretends to provide regulation tools for governments and urban decision makers to easily implement green urban regeneration project into planning strategies. First, it analyses a set of initiatives, implemented in policies, which have been carried out through the so-called "green factors". These Green factors promote increased green areas in cities. They started in Berlin and Hamburg, Germany, during the 1990s with the Biotope Area Factor (BAF) [25]. Similarly, the Greenspace Factor was implemented (2001) in a new urban development in Malmö, Sweden (Greenspace Factor) [26]. Similarly, in 2007, the City of Seattle developed its Green Factor (Green Factor) [27]; to name but a few. Through this exploration it initiates a methodology to create planning tools for policy makers to implement such a green urban intervention into urban regulations.

The paper identifies 6 urban instruments to be used in Spain: From the highest-level planning document (Municipal General Urban Plan, similar to Official Community Plans), to lower level documents like Special Urban Plans; and Urban Regulations; applied to both Building and Urban scales. It includes an extensive analysis on climate change urban solutions and their integration into these urban instruments as well as the development of by-law drafts to facilitate the implementation of adaptation measures. It analyses broad information which is extrapolated to an evaluative tool, based on excel sheets, to help local and regional governments and policy makers implement these strategies. This information is related to possible adaptation measures, criteria for the good implementation at local urban scale, and additional aspects such as responsibilities, penalties, etc. It is divided in 3 categories, corresponding to the identified climate risks: heatwaves, flooding, and droughts. As a result, 124 measures were connected to the 6 identified urban instruments but easily sorted by climate risk categories. These diverse measures are translated into by-law articles which can be included in the different 6 planning levels.

It finally deeply develops 2 planning instruments, urbanization by-law and building by-law, which integrates part of the identified solutions are complemented with the necessary criteria and observations for their good implementation.

\section{CONCLUSION AND DISCUSSION}

This research shows the potential of green urban infrastructure interventions to ameliorate climate change consequences. It classifies green urban interventions into two major categories. It analyses two case studies where green urban strategies have been applied in both an urban space and in a building renovation. It provides data on how these green urban interventions contribute to climate change mitigation (in terms of energy savings and reduction of $\mathrm{CO}_{2}$ emissions), as well as on climate change adaptation (in terms of reducing the urban heat island and the risk of floods by influencing on stormwater runoff); and contributing to a healthier and more resilient urban environments.

Results demonstrate that by greening a certain area of a building, according to the Balmaseda case study, the energy demand by buildings would be reduced by $10-15 \%$ [including a $100 \%$ reduction for cooling]. This means that the $\mathrm{CO}_{2}$ emitted to generate this energy would also be reduced by 10 $15 \%$; as for the contribution to mitigate climate change. Moreover, for the contribution to adaptation solutions, results show how greenery contributes to reduce hot spots and urban heat island of a city by reducing the external air temperature by around $2^{\circ} \mathrm{C}$. Finally, in terms of the capacity of greenery to trap air pollutants, the research shows that in the Balmaseda case study, proposed greenery in the building would trap around $768.38 \mathrm{~kg}$ of $\mathrm{CO}_{2}$ per year. While in the urban space case study of Amurrio, results show the proposed green intervention would trap around $17,131.87 \mathrm{~kg}$ of $\mathrm{CO}_{2}$.

Thus, for climate change mitigation solutions, it makes more sense to implement energy efficiency solutions in buildings, more than in urban space. Besides, by just greening building envelopes, modest results are achieved for reducing the energy efficiency, therefore these should be combined by highly insulated envelope solutions. Whereas the climate change adaptation solutions are more efficient to implement in broad area of a city, in order to significantly reduce urban hot spots, and ameliorate the risk of floods.

Therefore, this paper demonstrates that by greening certain areas of a city, climate change consequences can be reduced creating healthier and more resilient urban environments. However, it suggests more ambitious green urban interventions should be implemented in order to contribute to the objectives of the Paris Agreement. In addition, more research studies should be addressed, in order to achieve more accurate data, since many other environmental aspects of green urban infrastructure interventions have been yet scarcely analysed. This includes a cost and benefits assessment; contribution to urban health and eco-friendlier environments; compilation of good practices and case studies; among others.

Besides, this paper provides an evaluative tool to help local and regional governments and policy makers implement these strategies. However, it highlights the difficulties found in introducing such green urban interventions into real urban projects. After analysed experiences, in Amurrio and Balmaseda case studies, two main barriers were found: such green urban interventions are something new and municipal technicians and politicians are sceptical about them. The lack of expertise and experiences on this matter is still notable. 
International green urban examples are not enough as convincing arguments. Few urban designers or landscape architects may have the expertise on how to deal with such projects, but it is still quite difficult to find experienced contractors, builders or municipal technicians with this expertise. Besides, when few public green tenders try to promote these kinds of green urban interventions, they often result to be declared null.

Thus, it is not only a matter of governments deciding to implement an overall green urban intervention, in order to meet their international compromises (like the Paris Agreement); it means a more thorough implication should be planned to achieve it. Deep training courses should be addressed for all the agents involved in urban developments and regeneration projects; from designers to developers, including builders, decision makers, urban lawyers, technicians, etc.

Definitely, this research shows more ambitious green urban interventions should be implemented in order to achieve the Paris Agreement. It also highlights the need for a deeper implication of all the agents involved in these kinds of green urban regeneration projects. If we all agree we should definitely respond to the calls for urgent actions in order to limit climate change impacts, we all should then hold our hands in the same direction and broadly spread into the community the best and fastest way to achieve these "urban regreeneration" projects.

\section{REFERENCES}

[1] The Paris Agreement, https://unfccc.int/process-andmeetings/the-paris-agreement/the-paris-agreement/, accessed on Jun. 26, 2019.

[2] IPCC Press Release, 2018/10/08. https://www.ipcc.ch/site/assets/uploads/2018/11/pr_181 008_P48_spm_en.pdf/, accessed on Jun. 26, 2019.

[3] Nature-Based Solutions; European Commission, Policy Topics Online, https://ec.europa.eu/research/environment/index.cfm?pg =nbs/, accessed on Jul. 01, 2019.

[4] Mrowiec, M. (2016). Sustainable urban drainage infrastructure. Problemy Ekorozwoju, 11(2): 113-118.

[5] Schröder, R., Glandorf, S., Kiehl, K. (2018). Temporal revegetation of a demolition site-A contribution to urban restoration? Journal of Urban Ecology, 4(1). https://doi.org/10.1093/jue/juy010

[6] Radcliffe, J. (2017). The evolution of low impact development. Water e-Journal. 2: 1-17.

[7] Roehr, D., Laurenz, J., Kong, Y. (2008). Green envelopes: contribution of green roofs, green facades, and green streets to reducing stormwater runoff, $\mathrm{CO}_{2}$ emissions, and energy demand in cities. International Low Impact Development Conference, Seattle, pp. 1-8.

[8] Mathey, J., Arndt, T., Banse, J., Rink, D. (2018). Public perception of spontaneous vegetation on brownfields in urban areas-Results from surveys in Dresden and Leipzig (Germany). Urban Forestry \& Urban Greening, 29: 384392. https://doi.org/10.1016/j.ufug.2016.10.007

[9] Laurenz, J., Roehr, D. (2008). Living Skins, Opportunities, Critique and Appropriateness of Green Facades. World Sustainable Building, Melbourne.

[10] Bonoli, A., Conte, A., Maglionico, M., Stojkov, I. (2013).
Green roofs for sustainable water management in urban areas. Environmental Engineering and Management Journal. 12(s11): 153-156.

[11] Zinco Green Roof Systems. Online https://zincogreenroof.com/green-roof-systems/, accessed on Jul. 02, 2019.

[12] Carponi, M.S. (1993). Research project: Relevamiento del Arbolado Urbano de la Ciudad de Paraná. Entre Ríos University, Argentina.

[13] Rodriguez-Rojas, M.I. (2015). Universidad de Granada (eds) Guía para la Integración de los Sistemas Urbanos de Drenaje Sostenible en el Proyecto Urbano, pp. 68-82.

[14] Liu, K., Baskaran, B. (2003). Thermal Performance of Green Roofs Through Field Evaluation. North American Green Roof Infastructure Conference, Canada, pp. 1-10.

[15] Hoyano, A. (1998). Climatological uses of plants for solar control and the effects on the thermal environment of a building. Energy and Buildings, 11(1-3): 181-199. https://doi.org/10.1016/0378-7788(88)90035-7

[16] Holm, D. (1989). Thermal improvement by means of leaf cover on external walls - A simulation model. Energy and Buildings, 14: 19-30. South Africa.

[17] McPherson, E.G., Nowak, D.J. (1993). Chicago's Evolving Urban Forest: Initial report of the Chicago Urban Forest Climate Project. North-eastern Forest Experiment Station, Radnor, Pennsylvania, 40-41.

[18] Laurenz, J. (2005). Natural envelope: The green element as a boundary limit. The 2005 World Sustainable Building Conference, Tokyo, pp. 4653-4660.

[19] Dimoudi, A., Nicolopoulou, M. (2003). Vegetation in urban environment: Microclimatic analysis and benefits. Energy and Buildings, 35(1): 69-76. https://doi.org/10.1016/S0378-7788(02)00081-6

[20] Rosenzweig, C., Solecki, W.D., Slosberg, R.B. (2006). New York city's heat island with urban forestry, living roofs and light surfaces. New York State Energy Research and Development Authority, NY.

[21] Honjo, T., Narita, K., Sugawara, H., Mikami, T., Kimura, K., Kuwata, N. (2002). Observation of thermal effect of Shinjuku Gyoen Park. AMS Fourth Symposium on the Urban Environment, Norfolk, VA, pp. 84-85.

[22] Reynolds, J.S. (2002). Courtyards. Aesthetic, Social and Thermal Delight. John Wiley \& sons Inc., NY.

[23] The city of Toronto and Ryerson University. 2005, Report on the Environmental Benefits and Costs of Green Roof Technology for the City of Toronto, https://web.toronto.ca/wpcontent/uploads/2017/08/8f39-Report-on-theEnvironmental-Benefits-and-Costs-of-Green-RoofTechnology-for-the-City-of-Toronto-Full-Report.pdf/, accessed on Jul. 5, 2019.

[24] Schaefer, V., Rudd, H., Vala, J. (2004). Urban Biodiversity. Captus Press, Ontario, 342 pages

[25] Biotope Area Factor (BAF). (1994). Berlin, Germany. https://www.berlin.de/senuvk/umwelt/landschaftsplanun g/bff/index_en.shtml/, accessed on Jul. 5, 2019.

[26] Greenspace Factor. (2001). Malmö, Sweden. https://malmo.se/download/18.d8bc6b31373089f7d980 008924/1491301018437/greenspacefactor_greenpoints_ grabs.pdf/, accessed on Jul. 5, 2019.

[27] Green Factor. (2007). Seattle, US. https://www.seattle.gov/sdci/codes/codes-we-enforce(a-z)/seattle-green-factor/, accessed on Jul. 5, 2019. 